\title{
PENEGAKAN HUKUM TERHADAP PUNGUTAN LIAR PADA PENGUJIAN KENDARAAN BERMOTOR (PKB) DI DINAS PERHUBUNGAN KABUPATEN AGAM OLEH SATUAN TUGAS SAPU BERSIH PUNGUTAN LIAR
}

\author{
Sudarman \\ Program Magister Ilmu Hukum Universitas Ekasakti \\ Email: Sudarmanakang69@gmail.com
}

\begin{abstract}
All forms of unofficial levies that have no legal basis, such levies are named as illegal fees as stipulated in Presidential Regulation No. 87 of 2016. Illegal charges as a form of extortion crime should be prevented and eradicated because it has damaged the joints of life in society, nation and The eradication of illegal levies should be done in an integrated manner by involving Saber Pungli Task Force so as to manifest law enforcement against the perpetrator by giving severe sanction to cause deterrent effect. In practice, law enforcement against perpetrators is still not optimal because it still faces obstacles as happened in Agam District Transportation Department
\end{abstract}

Keywords: Penegakan Hukum, Tindak Pidana, Pungutan Liar.

\section{PENDAHULUAN}

Sektor pelayanan publik khususnya sektor transportasi pada Pengujian Kendaraan Bermotor (PKB) merupakan salah satu sektor yang paling rentan terhadap aktifitas pungutan liar. Uang pungutan liar masuk ke kantong oknum pegawai dan Keuangan Daerah dirugikan. Sementara itu banyak Angkutan Barang dan angkutan Orang yang Yang Tidak laik Jalan Beroperasi namun tidak dikenakan sanksi, sehingga jalan-jalan menjadi cepat rusak. $^{1}$

Pungutan liar merupakan salah satu kejahatan yang dilakukan oleh setiap subyek hukum, baik orang maupun badan hukum yang secara langsung maupun tidak langsung

\footnotetext{
${ }^{1}$ Koran Kompas pada artikel "Jalan Rusak Buka Peluang Pungutan Liar" Minggu, 27 Maret 2011
}

terkait dengan penyalahgunaan keuangan negara. $^{2} \quad$ Akibat tindak pidana Korupsi berdampak sangat luas, bukan hanya menyangkut keuangan negara, tetapi juga mampu merusak sistem pemerintahan, perekonomian dan pembangunan.

Terpuruknya perekonomian dan pembangunan di Indonesia yang terus menerus pada saat ini mempengaruhi sendisendi kehidupan di dalam masyarakat, berbangsa dan bernegara.

Pungutan liar tidak harus merugikan keuangan negara atau perekonomian negara. ${ }^{3}$ Pungutan liar merupakan perbuatan tercela

${ }^{2}$ Niniek Suparni dan Baringin Sianturi, Bunga Rampai Korupsi, Gratifikasi, dan Suap, Miswar, Jakarta, 2011, hlm. 8

3 Ermansjah Djaja, Tipologi tindak Pidana Korupsi di Indonesia, Mandar Maju, Bandung, 2010, hlm.53-85 
yang dilakukan untuk menguntungkan diri sendiri dengan penyalahgunaan kekuasaan, memaksa orang lain untuk memberikan keuntungan finansial, melanggar kepercayaan dan merusak mental para pegawai negeri.

Nilai pungutan liar terhadap pelaku usaha transportasi darat ditaksir cukup besar. Menurut penelitian Himpunan Pengusaha Indonesia (HIPMI) Research Center, hasil hitungan total pungutan liar dari proses administrasi kendaraan hingga kutipan kepada sopir di jalan mencapai lebih dari Rp. 25 triliun tiap tahun. Tiap perusahaan transportasi menyisihkan sedikitnya 25 persen pendapatan untuk membayar pungutan liar. Pungutan itu terjadi pada saat pengurusan administrasi maupun di jalan raya. $^{4}$ Akibatnya para operator angkutan harus mencari akal agar biaya operasi kendaraan dapat ditekan serta mengupayakan "kanibalisasi" suku cadang angkutan, sehingga tidak heran jika banyak angkutan yang tidak laik jalan masih beroperasi dijalan raya sehingga faktor keselamatan mereka kesampingkan demi keuntungan.

\section{Melihat banyaknya Angkutan Orang} dan Barang yang tidak laik jalan masih beroperasi di tengah jalan, dikembalikan lagi pada pengawasan dan kontrol Pada Dinas Perhubungan yakni di Bidang Pengujian Kendaraan bermotor .Adanya pungli (pungutan liar) yang terjadi di Bidang
Pengujian (Keur) mengakibatkan Angkutan Orang dan Angkutan Barang yang overload serta yang tidak laik jalan tetap lolos dan melanjutkan perjalanan. Seharusnya kendaraan tersebut tidak lagi boleh beroperasi ternyata dengan adanya pungutan liar yang dilakukan oleh oknum-oknum maka kendaraan tersebut lolos dari Pengujian Kendaran Bermotor serta melakukan aktifitas di jalan raya.

Pungutan liar dilarang dalam Pasal 418 KUHP yaitu kejahatan jabatan serta pungutan liar juga melanggar Undang-undang Nomor 31 Tahun 1999 juncto Undang-undang Nomor 20 Tahun 2001 tentang Pemberantasan Tindak Pidana Korupsi. Namun praktek ini terjadi setiap hari di semua Kota di Indonesia. Pemerintah bukannya tidak mengetahui persoalan akut ini, akan tetapi belum ada upaya serius untuk memberantas pungutan liar atau menghukum pelakunya.

Korupsi dalam bentuk pungutan liar bukan lagi sekedar masalah negara berkembang seperti Indonesia, tetapi telah menjadi masalah dunia. Majelis Umum Perserikatan Bangsa-Bangsa (PBB) memandang perlu mengadopsi "United Nations Convention Againts Corruption" (UNCAC) untuk memerangi korupsi di seluruh dunia. Indonesia menjadi salah satu negara yang telah meratifikasi konvensi tersebut melalui Undang-undang Nomor 7

\footnotetext{
${ }^{4}$ Majalah Tempo, 15 Februari 2012, hlm.12
} 
Tahun 2006 tentang Pengesahan United Nations Convention Againts Corruption. ${ }^{5}$

Pungutan Liar memang telah menjadi ancaman nyata bagi kelangsungan bangsa ini. Pungutan liar di Indonesia seperti tidak ada habis-habisnya dari tahun ke tahun, bahkan perkembangannya semakin meningkat, baik dalam jumlah kasus dan kerugian negara maupun kualitasnya. Perkembangan korupsi akhir-akhir ini nampak semakin sistematis dan terpola. Luas lingkupnya juga telah menyentuh seluruh aspek kehidupan masyarakat dan lintas batas negara. ${ }^{6}$ Oleh sebab itu, secara nasional disepakati bahwa korupsi bukan saja sebagai kejahatan luar biasa, tetapi juga sebagai kejahatan transnasional. $^{7}$

Tingginya "biaya siluman" juga membuat Operator Angkutan menekan upah sopir. Para sopir terpaksa lembur untuk mengejar setoran. Akibatnya, mereka kelelahan dan ceroboh saat menyetir. Ini pula yang menjadi salah satu pemicu besarnya angka kecelakaan. Akibatnya, para pengusaha harus mencari akal dengan menekan ongkos. Kondisi ini mengakibatkan "kanibalisasi" suku cadang angkutan umum lazim dilakukan. Sehingga tidak heran jika banyak bus dengan

5 Tjandra Sridjaja Pradjonggo, Sifat Melawan Hukum dalam Tindak Pidana Korupsi, Indonesia Lawyer Club, Surabaya, 2010, hlm. 2-3.

${ }^{6}$ Marwan Effendy, Pengadilan Tindak Pidana Korupsi, Lokakarya Anti Korupsi Bagi Jurnalis, Surabaya, 2007, hlm.1.

7 Wiyono,R, Pembahasan Undang Undang Pemberantasan Tindak Pidana Korupsi, Jakarta, 2006, hlm.10 rem aus atau tanpa spion tetap digenjot untuk menutup biaya. Faktor keselamatan mereka kesampingkan demi keuntungan.

Berbagai lembaga pengawas eksternal, juga telah dibentuk untuk melakukan kontrol terhadap kinerja aparatur penegak hukum dalam menjalankan fungsi dan wewenangnya secara transparan, seperti Komisi Yudisial, Komisi Kejaksaan, Komisi Kepolisian Nasional. Hal ini sebagai wujud dari fungsi pemberdayaan masyarakat yang diharapkan dapat menjadi mitra yang mampu bersinergi secara dinamis dan harmonis dengan pengawasan masing-masing internal institusi penegak hukum, sehingga harapan masyarakat untuk memiliki aparat penegak hukum yang bersih dan jujur dapat tercapai.

Lemahnya integritas moral yang turut melemahkan disiplin dari aparatnya, lemahnya sistem, lemahnya mekanisme di berbagai sektor birokrasi, seperti dikeluhkan pengusaha kecil maupun pengusaha asing, karena masih banyaknya mata rantai yang harus dilalui untuk memperoleh suatu pelayanan publik. Keadaan yang demikian menyebabkan suburnya pungutan liar sebagai salah satu bentuk perbuatan korupsi. Kelemahan sistem tersebut tidak dapat berdiri sendiri. Sistem adalah produk dari integritas moral, dan untuk memperbaiki sistem tergantung pada integritas moral, karena yang dapat berfikir perlunya diperbaiki sistem ialah yang bermoral. Orang yang tidak bermoral atau bermoral rendah meskipun tidak mungkin 
terdorong untuk memperbaiki sistem karena kelemahan sistem itu sendiri diperlukannya untuk melakukan penyelewengan. Pola perbuatan ini sudah menjadi salah satu gejala umum yang sulit diberantas, karena korupsi ini dilakukan dengan rapi. Selain itu umumnya dilakukan oleh kalangan yang berpendidikan tinggi, sehingga pemberantasannya sering menghadapi hambatan. ${ }^{8}$

Kompleksitas permasalahan di atas memang menjadi dilematis bagi pemerintah saat ini. Upaya untuk menimalisir terus dilakukan secara berkesinambungan, dengan perbaikan-perbaikan dan penyempurnaan sistem hukum, yang meliputi substansi hukum (Legal Substance), struktur hukum ( Legal Structure) dan kultur hukum (Legal Culture). Berbagai institusi penegak hukum pun telah berbenah diri dengan melakukan pembaharuan internal dengan melibatkan kalangan-kalangan eksternal yang kompeten dan mempunyai kepekaan serta kepedulian yang tinggi terhadap pembangunan hukum. ${ }^{9}$

Upaya penegakan hukum memerangi pungutan liar, selama ini Kementerian Perhubungan, instansi penegak hukum, dan pemerintah daerah berjalan sendiri-sendiri. Tidak ada gerakan serentak dan serius untuk memeranginya. Bahkan banyak pejabat, baik pusat maupun daerah, yang sengaja

${ }^{8}$ Edwin H. Sutherland "white collar crime", http://www.fbi.gov/aboutus/investigate/white collar/whi tecollarcrim/, diakses tanggal 21 November 2017

${ }^{9}$ Chaerudin (et.al), Strategi Pencegahan dan Penegakan Hukum Tindak Pidana Korupsi, PT. Refika Aditama, Bandung, 2009, hlm 8 membiarkan praktek ini karena menikmati setoran dari pelaku pungutan liar $^{10}$

Adapun alasan penulis memilih kasus pungutan liar di Pengujian Kendaraan Bermotor (PKB) ini dengan dasar pertimbangan bahwa upaya memberantas pungutan liar oleh instansi-instansi penegak hukum selama ini berjalan sendiri-sendiri, tidak ada gerakan serentak dan serius untuk memeranginya. Kasus pungutan liar yang terjadi, tidak banyak yang terangkat atau diproses secara hukum. Terungkapnya kasus pungutan liar di Dinas Perhubungan Kabupaten Agam di bidang Pengujian Kendaraan Bermotor (PKB) oleh Satuan Tugas (Satgas) Pungli Kabupaten Agam Dalam rangka Operasi Tangkap Tangan (OTT) menemukan petugas di lapangan sedang melakukan pungutan liar dalam pembayaran Biaya Uji Kendaraan (KIUR) Kendaraan.

Berdasarkan latar belakang pemikiran di atas, maka permasalahan yang dibahas dalam tulisan ilmiah ini adalah sebagai berikut:

1. Bagaimanakah penegakan hukum terhadap pungutan liar pada Pengujian Kendaraan Bermotor (PKB) Dinas Perhubungan Kabupaten Agam oleh Satuan Tugas Sapu Bersih Pungutan Liar (Saber Pungli) Kabupaten Agam?

10 Denny Indrayana, Cerita di Balik Berita, Jihad Melawan Mafia, PT. Bhuana Ilmu Populer, Jakarta, 2011, hlm.15 
2. Kendala-kendala apakah yang dihadapi oleh Satuan Tugas Sapu Bersih Pungutan Liar (Saber Pungli) Kabupaten Agam dalam penegakan hukum terhadap pungutan liar pada Pengujian Kendaraan Bermotor (PKB) Dinas Perhubungan Kabupaten Agam?

\section{METODE PENELITIAN}

Penelitian ini adalah suatu penelitian yang bersifat deskriptif analitis, yaitu suatu penelitian yang menggambarkan tentang penegakan hukum terhadap pungutan liar pada Pengujian Kendaraan Bermotor (PKB) Dinas Perhubungan Kabupaten Agam oleh Satuan Tugas Sapu Bersih Pungutan Liar (Saber Pungli) Kabupaten Agam serta kendalakendala yang dihadapinya. Metode pendekatan yang digunakan dalam penelitian ini adalah yuridis normative, yang didukung pendekatan yuridis empiris.

Pendekatan yuridis normatif. yaitu pendekatan yang dilakukan dengan cara mempelajari ketentuan-ketentuan dan peraturan perundang-undangan. ${ }^{11}$ Pendekatan yuridis empiris dilakukan dengan cara mengumpulkan semua bahan dan data yang diperoleh dari lapangan yang berhubungan dengan permasalahan yang diteliti.

11 Ronny Hanitijo Soemitro, Metodologi Penelitian Hukum dan Jurimetri, Ghalia Indonesia, Jakarta, 1990, hlm. 23

\section{HASIL DAN PEMBAHASAN}

Penegakan Hukum Terhadap Pungutan Liar Pada Pengujian Kendaraan Bermotor (PKB) Dinas Perhubungan Kabupaten Agam oleh Satuan Tugas Sapu Bersih Pungutan Liar (Saber Pungli) Kabupaten Agam

Penelitian ini dilaksanakan di Kabupaten Agam, khususnya pada Unit Pelaksana Teknis Dinas Pengujian Kendaraan Bermotor Dinas Perhubungan Kabupaten Agam, dikarenakan Satgas Saber Pungli Kabupaten Agam pada tanggal 12 September 2017 melakukan Operasi Tangkap Tangan (OTT) di Dinas Perhubungan Agam terhadap Kasi Pengujian Kendaraan Bermotor dan Perbengkelan Dishub Agam yang melakukan pungutan liar dengan kegiatan pengurusan, pemeriksaan/pengujian kendaraan bermotor (KIR). Dari transaksi terakhir, petugas menemukan pembayaran tidak sesuai dengan semestinya.

Berdasarkan hasil wawancara dengan Bapak Aksalmadi diperoleh penjelasan bahwa:

"Sebenarnya masyarakat ada yang melaporkan tentang adanya pungutan liar pada berbagai dinas yang ada di Kabupaten Agam, namun laporan yang diperoleh tidak semuanya disertai dengan bukti-bukti tentang dugaan pungutan liar.. Laporan yang bersumber dari masyarakat secara pribadi biasanya kurang dilengkapi dengan bukti-bukti awal sebagai pendukung adanya dugaan pungli. Demikian juga dengan laporan yang bersumber dari lembaga swadaya masyarakat (LSM umum) biasanya juga belum disertai dengan bukti-bukti pendukung tentang dugaan adanya 
pungli. Kebenaran laporan dugaan tidak ditentukan oleh disertai atau tidaknya laporan dengan alat bukti pendukung, meskipun laporan dugaan tindak pidana korupsi tidak disertai dengan alat bukti pendukung, namun Satgas Saber Pungli tetap menindaklanjuti laporan yang masuk tersebut". ${ }^{12}$

Berdasarkan hasil wawancara dengan Bapak Yosefriawan Kepala Dinas Perhubungan Kabupaten Agam diperoleh penjelasan sebagai berikut:

"Sebagai Kepala Dinas, pihaknya memang terus mengamati barangkali terjadi praktik percaloan serta pungli di UPTD Pajak Kendaraan Bermotor/Uji Kir. Dia tidak memungkiri praktik tidak terpuji itu masih ada di instansinya tapi begitu terpantau, langsung diambil tindakan.Masih adanya praktik tersebut, karena para pejabat ini sudah terlalu lama berkutat di pekerjaannya sehingga tercipta mata rantai pungli dan calo. Pihaknya sudah memastikan bahwa apabila ada anggotanya yang melakukan pungutan liar terhadap masyarakat dalam pelayanan uji kendaraan bermotor dipastikan akan ditindak dan diberi sanksi“. ${ }^{13}$

Berkaitan dengan pentingnya Pengujian

kendaraan bermotor selanjutnya dikatakan bahwa:

"Pengujian kendaraan bermotor penting untuk dilakukan, dikarenakan selain untuk mengetahui kelayakan kendaraan tersebut beroperasi, juga untuk memastikan tidak membahaya-

${ }^{12}$ Hasil Wawancara dengan Bapak Komisaris Polisi (Kompol) Aksalmadi, Ketua Pelaksana Tugas Satuan Tugas Sapu Bersih Pungutan Liar (Saber Pungli) Kabupaten Agam pada tanggal 10 Mei 2018 di Lubuk Basung.

${ }^{13}$ Hasil Wawancara dengan Bapak Yosefriawan, Kepala Dinas Perhubungan (Dishub) Kabupaten Agam, pada tanggal 18 Mei 2018 di Lubuk Basung. kan keselamatan orang lain ketika di jalan umum, seperti yang sering kita jumpai di media maupun secara langsung, mulai truk yang roda as nya patah ataupun asap kendaraan yang cukup parah pekatnya, inilah yang terkadang dimanfaatkan oknum pegawai untuk melakukan pungutan yang tidak sesuai dengan ketentuan yang telah ditentukan oleh peraturan perundang-undangan". ${ }^{14}$

Ketentuan mengenai kewajiban Dinas Perhubungan untuk melakukan pengujian kendaraan bermotor diatur dalam Pasal 53 ayat (3) Undang-undang Nomor 22 Tahun 2009 tentang Lalu Lintas dan Angkutan Jalan yang menyatakan bahwa: "kegiatan pemeriksaan dan pengujian fisik kendaraan bermotor sebagaimana dimaksud pada ayat (2) huruf a dilaksanakan oleh:

1. Unit pelaksana pengujian pemerintah kabupaten/kota;

2. Unit pelaksana agen tunggal pemegang merek yang mendapat izin dari Pemerintah; atau

3. Unit pelaksana pengujian swasta yang mendapatkan izin dari Pemerintah.

Berdasarkan hasil penelitian yang penulis lakukan berkaitan dengan penegakan hukum terhadap pungutan liar pada Pengujian Kendaraan Bermotor (PKB) Dinas Perhubungan Kabupaten Agam oleh Satuan Tugas Sapu Bersih Pungutan Liar (Saber Pungli) Kabupaten Agam diperoleh penjelasan sebagai berikut: "Ada beberapa faktor yang menyebabkan penegakan hukum

${ }^{14}$ Hasil Wawancara dengan Bapak Yosefriawan, Kepala Dinas Perhubungan (Dishub) Kabupaten Agam, pada tanggal 18 Mei 2018 di Lubuk Basung. 
terhadap terjadinya pungutan liar pada Dinas Perhubungan Kabupaten Agam tidak optimal, yaitu: ${ }^{15}$

1. Faktor undang-undang

Pengaturan perbuatan apa saja yang masuk dalam pungutan liar belum diatur secara tegas atau dapat dikatakan pengaturanya masih bersifat umum. Pengaturan suatu masalah dalam perundang-undangan didasari pokok pikiran, bahwa ada sesuatu "kepentingan hukum" yang perlu mendapat pengaturan dan perlindungan hukum. ${ }^{16}$ Satgas 1 Intelejen yang bertugas untuk melakukan pemetaan terhadap instansi-instansi yang rawan melakukan tindak pidana pungutan liar di Agam. Karena belum adanya undang-undang, dengan demikian dalam merinci tindakan yang rawan dengan pungutan liar oleh Satgas 1 menjadi terhambat yang kemudian menyebabkan kurang efektifnya Satgas Saber Pungli.

2. Faktor Penegak Hukum

Yang dimaksud dengan penegak hukum di sini yaitu Satgas Saber Pungli.

3. Faktor Sarana atau Fasilitas

Faktor-faktor yang mempengaruhi penegakan hukum pungutan liar di Agam

15 Hasil Wawancara dengan Bapak Komisaris Polisi (Kompol) Aksalmadi, Ketua Pelaksana Tugas Satuan Tugas Sapu Bersih Pungutan Liar (Saber Pungli) Kabupaten Agam pada tanggal 10 Mei 2018 di Lubuk Basung.

${ }^{16}$ Muchamad Iksan, Hukum Pelindungan Saksi dalam Sistem Peradilan Pidana Indonesia, Muhammadiyah University Press, Surakarta, 2012, hlm. 120-121. dalam hal faktor sarana atau fasiilitas adalah berkas yang tidak lengkap, kurangnya komunikasi antar lembaga, kurangnya sarana/fasilitas dan adanya tugas sampingan para anggota. Berbagai permasalahan yang telah diuraikan di atas menyebabkan kinerja Satuan Tugas Sapu Bersih Pungutan Liar di Agam tidak bekerja dengan maksimal jadi mempengaruhi kurang efektifnya penegakan hukum kasus pungutan liar di Agam.

4. Faktor Masyarakat

Faktor kultural kesadaran hukum masyarakat membantu pelaksanaan atau penegakan hukum pada suatu negara dengan mulus.15 Dalam hal ini penulis telah melakukan wawancara terhadap beberapa masyarakat di Agam yang mewakili beberapa latar belakang yang berbeda dengan mengajukan pertanyaan terkait dengan keikutsertaan dalam pelaporan adanya pungutan liar. Dapat ditarik kesimpulan banyak masyarakat yang ingin melaporkan adanya pungutan liar tetapi mereka memilih untuk tidak melaporkan karena berbagai alasan.

5. Faktor Kebudayaan

Faktor kebudayaan sangat mempengaruhi efektivitas penanggulangan tindak pidana pungutan liar, masyarakat menganggap suap atau pungutan liar adalah hadiah atau tanda terima kasih, yang kemudian pemikiran yang seperti itu telah menjadi budaya di dalam kehidupan 
masyarakat di Indonesia. Di kalangan petugas atau aparatur negara selama mereka digaji kecil yang memiliki wewenang yang begitu besar maka pungutan liar akan berjalan terus.

Kendala-kendala yang Dihadapi Satuan Tugas Sapu Bersih Pungutan Liar (Saber Pungli) Kabupaten Agam Dalam Penegakan Hukum Terhadap Pungutan Liar Pada Pengujian Kendaraan Bermotor (PKB) Dinas Perhubungan Kabupaten Agam

Dalam penegakan hukum terhadap pungutan liar, Satuan Tugas Sapu Bersih Pungutan Liar (Satgas Saber Pungli) Kabupaten Agam, telah melaksanakan tugas sebagaimana yang telah ditentukan dalam Keputusan Bupati Agam Nomor 68 Tahun 2017 tentang Satuan Tugas Sapu Bersih Pungutan Liar (Satgas Saber Pungli) Di Kabupaten Agam, yaitu melakukan operasi tangkap tangan. Namun dalam pelaksanaan tugas tersebut masih menemui kendalakendala dalam penegakan hukumnya, sehingga menyebabkan kegiatan yang dilakukan tidak berjalan secara optimal atau menjadi kurang efektif.

Berdasarkan hasil penelitian yang penulis lakukan berkaitan dengan kendalakendala yang dihadapi Satuan Tugas Sapu Bersih Pungutan Liar (Saber Pungli) Kabupaten Agam dalam penegakan hukum terhadap pungutan liar pada Pengujian Kendaraan Bermotor (PKB) Dinas
Perhubungan Kabupaten Agam diperoleh penjelasan sebagai berikut: ${ }^{17}$

1. Tidak adanya undang-undang yang secara khusus mengatur mengenai pungutan liar

Tidak adanya undang-undang yang mengatur mengenai pungutan liar akan berimplikasi kepada tindakan mana saja yang bisa masuk ke dalam tindak pidana pungutan liar. Tidak adanya pengaturan secara pasti ini akan menyebabkan kesulitan dalam penjatuhan pidana atau sanksi, selain itu juga dapat menimbulkan ketidakpastian hukum dalam penegakan hukum pungutan liar.

2. Kurangnya partisipasi masyarakat dalam melaporkan adanya pungutan liar.

Dalam hal ini disebabkan oleh adanya sikap acuh tak acuh dari masyarakat mengenai tindak pidana pungutan liar, masyarakat yang tidak mengetahui mengenai Satgas Saber Pungli, kurang jelasnya dalam cara pelaporan masyarakat kepada Satgas Saber Pungli. pungutan liar ini telah menjadi budaya yang sudah biasa di dalam kehidupan masyarakat yang merupakan respon dari masyarakat yang menginginkan birokrasi yang tidak berbelit-belit, cepat dan keamanan yang terjamin. Selain sikap acuh tak acuh tersebut banyak juga masyarakat

\footnotetext{
${ }^{17}$ Hasil Wawancara dengan Bapak Komisaris Polisi (Kompol) Aksalmadi, Ketua Pelaksana Tugas Satuan Tugas Sapu Bersih Pungutan Liar (Saber Pungli) Kabupaten Agam pada tanggal 10 Mei 2018 di Lubuk Basung.
} 
yang tidak mengetahui mengenai Satgas Saber Pungli.

3. Pembuktian di lapangan yang sangat sulit. Pembuktian mengenai tindak pidana pungutan liar membutuhkan data-data yang sangat sulit dan komprehenshif, kecuali apabila pungutan liar tersebut dilakukan secara operasi tangkap tangan (OTT) maka akan lebih mudah juga apabila pungutan liar tersebut dibuktikan ketika tindak pidana itu dilakukan atau segara atau beberapa saat tindak pidana itu dilakukan.

4. Sarana dan fasilitas yang kurang mendukung.

Faktor sarana atau fasilitas yang memepengaruhi tidak efektivitasnya penegakan hukum kasus pungutan liar yaitu berkas yang tidak lengkap, kurangnya komunikasi antar lembaga, kurangnya sarana/fasilitas dan adanya tugas sampingan para anggota yang tergabung dalam Satgas Saber Pungli Kabupten Agam.

5. Kurang transparannya penanganan kasus pungli

Kurang transparannya dalam penanganan kasus pungli yang terjadi pada Dinas Perhubungan Kabupaten Agam maksudnya adalah semua berkas penanganan pungutan liar tersebut diminta oleh Bupati untuk dipelajari terlebih dahulu, sehingga berkas perkara masih belum bisa ditindaklanjuti untuk diproses melalui mekanisme sistem peradilan pidana.

6. Lemahnya pengawasan oleh inspektorat Pungutan liar yang terjadi pada Dinas Perhubungan Kabupaten Agam sesungguhnya tidak akan terjadi apabila pihak Inspektorat sebagai pengawas internal melakukan pengawasan dengan baik, termasuk juga dengan belum adanya tindak lanjut dari penanganan pungutan liar yang telah dilakukan penanganannya oleh Satgas Saber Pungli, seharusnya pihak Inspektorat menanyakan kepada Bupati terhadap perkembangan kasus tersebut sehingga dapat dituntaskan.

7. Tidak adanya sanksi pidana yang dijatuhkan kepada pelaku.

Dengan belum adanya tindak lanjut dari penanganan pungutan liar yang terjadi pada Dinas Perhubungan Kabupaten Agam, maka terhadap pelaku yang ditangkap karena melakukan pungutan liar tidak diberi sanksi pidana karena belum diselesaikan melalui mekanisme sistem peradilan pidana. Sanksi yang diberikan hanya sanksi administratif saja yang berupa dicopotnya pelaku dari jabatan sebagai Kepala Seksi Pengujian Kendaraan pada Dinas Perhubungan Kabupaten Agam. 


\section{PENUTUP}

Berdasarkan pembahasan sebagaimana yang telah dipaparkan di atas, maka penulis dapat menarik kesimpulan sebagai berikut:

Penegakan hukum terhadap pungutan liar pada Pengujian Kendaraan Bermotor (PKB) Dinas Perhubungan Kabupaten Agam oleh Satuan Tugas Sapu Bersih Pungutan Liar (Saber Pungli) Kabupaten Agam tidak optimal karena kasus pungutan liar tersebut tidak diteruskan ke tingkat penyidikan dan penuntutan serta pemeriksaan di sidang pengadilan, melalui sistem peradilan pidana,sehingga pelaku tidak dijatuhkan sanksi pidana tetapi hanya dijatuhkan sanksi administratif berupa pemberhentian dari jabatannya saja.

Kendala-kendala yang dihadapi oleh Satuan Tugas Sapu Bersih Pungutan Liar (Saber Pungli) Kabupaten Agam dalam penegakan hukum terhadap pungutan liar pada Pengujian Kendaraan Bermotor (PKB) Dinas Perhubungan Kabupaten Agam adalah: (1) tidak adanya undang-undang yang mengatur secara khusus mengatur pungutan liar, (2) kurang adanya partisipasi dari masyarakat dalam melaporkan adanya pungutan liar, (3) pembuktian di lapangan yang sangat sulit, (4) sarana dan fasilitas yang kurang mendukung bagi Satgas Saber Pungli, (5) kurang transparannya penanganan kasus pungli dan (6) lemahnya pengawasan oleh inspektorat serta (7) tidak adanya sanksi pidana yang dijatuhkan kepada pelaku.

\section{DAFTAR PUSTAKA}

\section{Buku-Buku}

Barda Nawawi Arief, Bunga Rampai Kebijakan Hukum Pidana, PT. Citra Aditya Bakti, Bandung, 2010

Chaerudin (et.al), Strategi Pencegahan dan Penegakan Hukum Tindak Pidana Korupsi, PT. Refika Aditama, Bandung, 2009

Ghuffan, Ahmad, dan Sudarsono. Hukum Kepegawaian Di Indonesia, Rineka Cipta, Jakarta, 1991

Gilang Andhika Gunawan, Tinjauan Kriminologis Terhadap Pungutan Liar Kepada Pengemudi Angkutan Antar Daerah, Fakultas Hukum Universitas Hasanuddin, Makassar 2013

Irwan Suwarto, Polri dalam Dinamika Ketatanegaraan Indonesia Modern, Ekasakti Press, Padang, 2003

Jimly Asshiddiqie, Agenda Pembangunan Hukum Nasional Di Abad Globalisasi, Cet.I, Balai Pustaka, Jakarta, 1998

Kumorotomo, Wahyu. Sistem Informasi Manajemen dalam Organisasi Organisasi Publik, Gadjah Mada University Press, Yogyakarta, 1994

Martiman Prodjohamijojo, Memahami DasarDasar Hukum Pidana Indonesia I. Pradnya Paramita, Jakarta, 1996

Marwan Effendy, Pemberantasan Korupsi dan Good Governance, Timpani, Jakarta, 2010

, Pengadilan Tindak Pidana Korupsi, Lokakarya Anti Korupsi Bagi Jurnalis, Surabaya, 2007

Niniek Suparni dan Baringin Sianturi, Bunga Rampai Korupsi, Gratifikasi, dan Suap, Miswar, Jakarta, 2011

\section{Peraturan Perundang-undangan}

Undang-Undang Dasar Negara Republik Indonesia Tahun 1945.

Undang-undang Nomor 1 Tahun 1946 tentang Peraturan Hukum Pidana (KUHP). 
Undang-undang Nomor 8 Tahun 1981 tentang Hukum Acara Pidana (KUHAP).

Undang-undang Nomor 31 Tahun 1999 tentang Pemberantasan Tindak Pidana Korupsi.

Undang-undang Nomor 20 Tahun 2001 tentang Perubahan atas UndangundangNomor 31 Tahun 1999 tentang Pemberantasan Tindak Pidana Korupsi.

Undang-undang Nomor 2 Tahun 2002 tentang Kepolisian Negara Republik Indonesia.

Undang-undang Nomor 22 Tahun 2009 tentang Lalu Lintas dan Angkutan Jalan.

Peraturan Pemerintah Nomor 58 Tahun 2010 tentang Perubahan atas Peraturan Pemerintah Nomor 27 Tahun 1983 tentang Pedoman Pelaksanaan KUHAP.

Peraturan Pemerintah Nomor. 55 Tahun 2012 Tentang Kendaraan.

Peraturan Presiden Nomor. 87 Tahun 2016 tentang Satuan Tugas Sapu Bersih Pungutan Liar.

Peraturan Menteri Perhubungan Nomor KM. 35 Tahun 2003 Tentang Penyelenggaraan Angkutan Orang di Jalan dengan Kendaraan Umum.

Peraturan Menteri Perhubungan Nomor PM 133 Tahun 2015 tentang Pengujian Berkala Kendaraan Bermotor.

Instruksi Menteri Dalam Negeri Nomor 180/3935/SJ tentang Pengawasan Pungutan Liar Dalam Penyelenggaraan Pemerintahan Dalam Negeri.

Peraturan Kapolri Nomor 23 Tahun 2010 tentang Susunan Organisasi Dan Tata Kerja pada Tingkat Kepolisian Resort Dan Kepolisian Sektor.

Peraturan Daerah Nomor .1 Tahun 2012 tentang Retribusi Jasa Umum.

Keputusan Bupati Agam Nomor 68 Tahun 2017 Tentang Satuan Tugas Sapu Bersih Pungutan Liar Di Kabupaten Agam. 